\title{
The Effect of FDI to Accelerate the Economic Growth of Bangladesh and Some Problems \& Prospects of FDI
}

\author{
Mohammad Omar Faruk
}

Lecturer, Eastern University, Dhaka, Bangladesh

\begin{abstract}
Foreign Direct Investment (FDI) has great impact on the development of a developing country like Bangladesh. The foreign investor seeks for new sources of investment where the developing country seeks for new sources of fund to develop the country. The FDI does not only bring sources of fund in a developing country but also new technology in a developing country. The FDI has the important role to develop the garments $\mathcal{E}$ weaving, telecommunication, banking and pharmaceuticals industry of Bangladesh. In this paper the role of FDI in economic growth (GDP) is analyzed to find out relationship between FDI and GDP in Bangladesh. To analyze the impact, The GDP has been taken as a dependent and FDI as an independent variable to run the regression analysis where the result shows that the FDI can explain about $83 \%$ data of GDP, $p$ value much less than 0.05 to reject null hypothesis and GDP changes 64.0709 units for changes of each unit of FDI. The correlation matrix shows the GDP and FDI is highly correlated (0.912024962) in perspective of Bangladesh economy, so the FDI has grater impact on GDP or Economic Growth of Bangladesh. Some of the problems and prospects of FDI in Bangladesh is also discussed in the paper.
\end{abstract}

Keywords: FDI, FDI and GDP, Problems and Prospects of FDI, FDI in Bangladesh Finance and Economic Growth. JEL Classification Code: F21

\section{INTRODUCTION}

$\mathrm{F}$ oreign Direct Investment (FDI) can play an important role for accelerating the economic growth [1], developing countries have begun to aggressively compete for FDI opportunities [2]. Globalization is changing the strategies of multinational companies (MNCs) and the way developing countries compete for FDI. FDI encourages the transfer of new business, technology and knowledge [3] and it allows the host economy or country to promote its products more widely in international arena. Policymakers and multilateral organizations have increasingly emphasized the importance of a sound investment climate and flow of FDI for promoting economic growth in developing countries [4]. The FDI has three components like Equity Capital, Intra Company Loan and Reinvested Earning.

FDI inflows generate jobs through new establishments and expanded activities, and indirectly increase competition within domestic markets [5] and facilitate the transfer of improved technology and management techniques [6]. For the investor, the potential benefits lie in penetrating a market, gaining access to raw materials, diversifying business activity, rationalizing production processes and overcoming some of the drawbacks of exporting, such as trade barriers and transport costs. FDI also enables companies to learn about the host market and how to compete in it [7].

FDI is a major source of external finance which means that countries with limited amount of capital can receive finance beyond national borders from wealthier countries. It opens new avenues of knowledge, transfer of technology [8], training of manpower, market networking, and many other spillover effects and externalities in the host countries.

Copyright $(92$ 2013, Asian Business Consortium | ABR
There should have the FDI opportunities to attract the foreign MNC, there are many FDI opportunities in Bangladesh but the FDI growth of our neighboring country (like India) is very high moreover the government should create more flexible opportunities and have more FDI [4].

This paper investigates the current status of FDI in Bangladesh, the importance of FDI for economic development of Bangladesh using regression analysis and the FDI policies that should be taken to attract the foreign companies in Bangladesh. The report also gives some suggestion that may be taken to improve the FDI growth in Bangladesh.

\section{LiTERATURE}

A number of studies find that FDI inflows have a strong and positive effect on economic growth [9]. In Russia, FDI appears to have been an essential force in supporting the economy during the initial chaos of transition [10]. Blomstrom [8] apply mixed fixed and random estimation to examine the relationship between FDI and growth in developing countries and find that there is a causal link between FDI and growth. Hsiao and Shen [11] found a feedback association between FDI and GDP in their time series analysis of the data from China. Using data on 80 countries for the period 1971-95, Choe [12] detects two-way causation between FDI and growth, but the effects are more apparent from growth to FDI.

Kafi, Uddin \& Islam [13] showed the problems and prospects of FDI in Bangladesh and they have identified some key factors to increase FDI in Bangladesh. In addition, 
Shimul et. al. [14] investigates the direction of causal link between FDI and economic growth measured by GDP in nineteen developing countries of South East Asia and Latin America using co-integration technique. The relationship between growing FDI stock and economic growth has motivated a voluminous empirical literature in developed and developing countries. Aitken et. al. [9] confirmed the existence of a positive and significant relationship between FDI and the economic growth in the United States.

Duasa [15], examined the causality between FDI and output growth in Malaysia, the study found no strong evidence of causal relationship between FDI and economic growth. This indicates that, in the case of Malaysia FDI does not cause economic growth, vice versa, but FDI does contribute to stability of growth as growth contributes to stability of FDI. Governments are liberalizing FDI regimes as they associate FDI with positive effects for economic development and poverty reduction in their countries [16].

In order to identify countries that have been successful in attracting FDI conducive to economic development, it thus seems necessary to rely at least partly on anecdotal and/or econometric evidence on the impact of FDI. For instance the evidence shows that countries such as Ireland [17] has benefited from FDI e.g. in terms of growing exports.

\section{Methodology}

The paper is based on secondary data collected from International Monetary Fund, World Economic Outlook Database, 2012, United Nations Conference of Trade and Development (UNCTAD) and Bangladesh Bank's FDI Survey Report 2011. Others data have been collected from Board of Investment (Bangladesh), World Investment Report and different national and international journal, publication, books, report, articles. The graph shows the trend of FDI from 2001 to 2010 where the regression analysis and correlation matrix analyze the data of FDI and GDP (at current price) from 1980 to 2011. The graph, regression analysis $(\mathrm{GDP}=f(\mathrm{FDI}))$ and correlation matrix is formed using Microsoft Excel 2007 to make the decision. A hypothesis is also made to reveal the impact of FDI on GDP.

TABLE 1: Selected empirical studies on FDI [18]

\begin{tabular}{|l|l|l|}
\hline Study & $\begin{array}{l}\text { Country / Level } \\
\text { of analysis }\end{array}$ & $\begin{array}{l}\text { Effects of FDI on growth and } \\
\text { productivity }\end{array}$ \\
\hline Caves [19] & $\begin{array}{l}\text { Australia, sec- } \\
\text { toral level, man- } \\
\text { ufacturing, 1966 }\end{array}$ & $\begin{array}{l}\text { Positive correlation FDI pres- } \\
\text { ence and } \\
\text { productivity in sector }\end{array}$ \\
\hline $\begin{array}{l}\text { Bal- } \\
\text { asubraman } \\
\text { yam } \text { et al. } \\
\text { [20] }\end{array}$ & $\begin{array}{l}46 \text { developing } \\
\text { countries, cross } \\
\text { section over } \\
1970-1995\end{array}$ & $\begin{array}{l}\text { Beneficial effect of FDI on real } \\
\text { GDP is greater in export promo- } \\
\text { tion (EP) countries than in import } \\
\text { substitution (IS) countries }\end{array}$ \\
\hline $\begin{array}{l}\text { Barrell and } \\
\text { Pain [6] }\end{array}$ & $\begin{array}{l}\text { UK and West } \\
\text { Germany, 1972- } \\
1995\end{array}$ & $\begin{array}{l}\text { Positive effect of FDI on over- } \\
\text { all technical progress }\end{array}$ \\
\hline $\begin{array}{l}\text { Borensztein } \\
\text { et al. [16] }\end{array}$ & $\begin{array}{l}69 \text { countries, } \\
\text { national level }\end{array}$ & $\begin{array}{l}\text { Weak positive correlation } \\
\text { between FDI } \\
\text { and per capita GDP growth }\end{array}$ \\
\hline
\end{tabular}

Copyright ( 92013 , Asian Business Consortium | ABR

\begin{tabular}{|c|c|c|}
\hline $\begin{array}{l}\text { Blomstrom } \\
\text { [8] }\end{array}$ & Mexico, 70s & $\begin{array}{l}\text { Positive correlation FDI pres- } \\
\text { ence and productivity in sec- } \\
\text { tor, but firms with large tech- } \\
\text { nology gaps do not learn. }\end{array}$ \\
\hline $\begin{array}{l}\text { Blomstrom } \\
\text { and Sjo- } \\
\text { holm [8] }\end{array}$ & $\begin{array}{l}\text { Indonesia, man- } \\
\text { ufacturing firms, } \\
1991 \\
\end{array}$ & $\begin{array}{l}\text { Positive effect on productivity } \\
\text { of domestic firms, but only for } \\
\text { 'non-exporters'. }\end{array}$ \\
\hline $\begin{array}{l}\text { Blomstrom } \\
\text { et al. } \\
{[21]}\end{array}$ & $\begin{array}{l}\text { Uruguay, manu- } \\
\text { facturing } \\
\text { plants, } 1988 \\
\end{array}$ & $\begin{array}{l}\text { Positive spillover effects on } \\
\text { domestic firms only with a } \\
\text { small technology gap. }\end{array}$ \\
\hline
\end{tabular}

\section{IMPACT OF FDI ON ECONOMIC DEVELOPMENT 4.1 STATUS OF GDP AND FDI IN BANGLADESH}

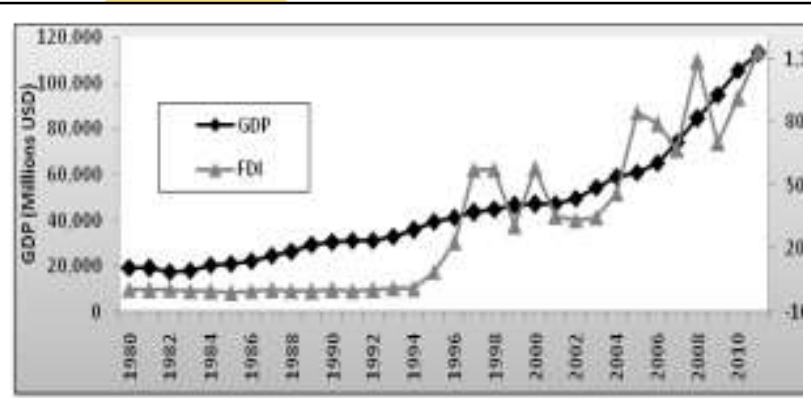

Fig. 1 GDP and FDI Inflow of Bangladesh

Source: Bangladesh Bank's FDI Survey Report 2011

\subsection{REGRESSION ANALYSIS}

Model Specification: GDPi $=\boldsymbol{\beta o}+\boldsymbol{\beta 1 F D I i}+\boldsymbol{\varepsilon}$

The model is used by Anower \& Kamal [22] to present the empirical relationship between FDI and GDP in South Asia, this model is also used by Ray [23] to show a cointegration analysis between FDI and GDP.

Where,

GDP $=$ Gross Domestic Product (Millions USD)

FDI $=$ Foreign Direct Investment (Million USD) iable

$\beta_{1}=$ Regression coefficients for the independent var-

$$
\begin{aligned}
\beta_{0} & =\text { constant term } \\
\mathrm{i} & =\text { different years } \\
\varepsilon & =\text { error }
\end{aligned}
$$

\section{Hypothesis:}

$\mathrm{H}_{0}=$ There is no relationship between FDI and GDP $\left(\beta_{1}=0\right)$

$\mathrm{H}_{1}=$ There is a relationship between FDI and GDP $\left(\beta_{1} \neq 0\right)$

\section{Result and Interpretation}

The regression shows a positive correlation between FDI and GDP, that reveals the contribution of FDI in the economic growth of Bangladesh. The data of FDI can explain $83.18 \%$ growth of GDP. Therefore the FDI has a strong role for the economic development of Bangladesh. So the FDI can have positive contribution in the development of Bangladesh Economy, especially different sector like Garments, Banking, Telecommunication, Fertilizer and other manufacturing sectors. 
TABLE 2: Regression Result

\begin{tabular}{|c|c|}
\hline \multicolumn{2}{|c|}{ Regression Statistics } \\
\hline Multiple R & 0.912024963 \\
\hline R Square & 0.831789532 \\
\hline Adjusted R Square & 0.826182517 \\
\hline Standard Error & 10714.5941 \\
\hline Observations & 32 \\
\hline
\end{tabular}

The data reveals there is very significant impact among two variables as the Significance F is much less than 0.05 and the Sum of Squares and Mean Squares are very high. Here F-statistics is greater than upper bound so the null hypothesis is clearly rejected.

TABLE 3: Regression Result

\begin{tabular}{|c|c|c|c|c|c|}
\hline ANOVA & \multicolumn{6}{|c|}{} \\
\hline & df & $\begin{array}{c}\text { Sum of } \\
\text { Squares }\end{array}$ & $\begin{array}{c}\text { Mean } \\
\text { Squares }\end{array}$ & F & $\begin{array}{c}\text { Signifi } \\
\text { cance F }\end{array}$ \\
\hline Regression & 1 & 17030724907 & 170307249 & 148.347 & $3.8445 \mathrm{E}-13$ \\
\hline Residual & 30 & 3444075801 & 114802526 & & \\
\hline Total & 31 & 20474800709 & & & \\
\hline
\end{tabular}

The coefficient of intercept is 25260.3286 and FDI is 64.0709 so it is clear that if FDI changes by 1 unit then the GDP will definitely change by 64.0709 . As p-value is much less than 0.05 therefore null hypothesis will be rejected. So it is clear that there is a strong impact of FDI in the growth or GDP of Bangladesh.

TABLE 4: Regression Result

\begin{tabular}{|c|c|c|c|c|c|c|}
\hline & Coefficients & $\begin{array}{c}\text { Standard } \\
\text { Error }\end{array}$ & $t$ Stat & P-value & Lower 95\% & Upper 95\% \\
\hline Intercept & 25260.3286 & 2514.3007 & 10.0467 & $4.10469-\mathrm{E}$ & 20125.4415 & 30395.2157 \\
\hline FDI & 64.0709 & 5.2604 & 12.1798 & $3.84454-\mathrm{E}$ & 53.3277 & 74.8142 \\
\hline
\end{tabular}

From the above analysis we can conclude that there is a high degree of correlation (0.912024962) between FDI and GDP. If the FDI increase then the GDP will obviously increase, consequently it will improve the economic growth, employment, per capita income and also lower inflation of the country. So the government should promote the foreign investors to invest in different prospective sectors like Agriculture, Service such as transportation, railway and air, electricity and power, fertilizer and cement.

\begin{tabular}{|c|c|c|}
\multicolumn{2}{|c|}{ TABLE 5: Correlation Matrix } \\
\hline & GDP & FDI \\
\hline GDP & 1 & \\
\hline FDI & 0.912024963 & 1 \\
\hline
\end{tabular}

So there is an important contribution of FDI on the economic development of Bangladesh. It is obvious that if FDI rises then GDP will definitely rise, the analysis also indicates that the FDI can develop the different sector of Bangladesh. So Bangladesh government should expose some opportunities of FDI to the foreign investors to Copyright (C) 2013, Asian Business Consortium | ABR promote some underdeveloped like software, IT, chemicals and high costly sector like Air Manufacturing Industry, Astronomy and Uranium Power Plant.

\section{FDI OPPORTUNITIES IN BANGLADESH}

\subsection{Opportunities of FDI in Bangladesh*}

Bangladesh is a winning combination with its competitive market, business-friendly environment and cost structure for FDI, some of the opportunities are as follows:

- Industrious Low-Cost Workforce: Bangladesh offers a well-educated, highly adaptive and industrious workforce with the lowest wages and salaries in the region. $57.3 \%$ of the population is under 25 , providing a youthful group for recruitment. The country has consistently developed a skilled workforce catering to investors needs. English is widely spoken, making communication easy.

- Strategic Location, Regional Connectivity and Worldwide Access: Bangladesh is strategically located next to India, China and ASEAN markets. As the South Asian Free Trade Area (SAFTA) comes into force, investors in Bangladesh will enjoy duty-free access to India and other member countries.

- Strong Local Market and Growth: Bangladesh has proved to be an attractive investment location with its 146.6 million populations and consistent economic growth leading to strong and growing domestic demand.

- Low Cost of Energy: Energy prices are the most competitive in Bangladesh. Transportation on green compressed natural gas is less than $20 \%$ of the diesel price.

- Proven Export Competitiveness: Bangladesh enjoys tariff-free access to the European Union, Canada, Australia and Japan. In Europe, Bangladesh enjoys $60 \%$ of the market share and is the top manufacturing exporter amongst 50 least developed countries.

- Competitive Incentives: Bangladesh offers the most liberal FDI regime in South Asia, allowing 100\% foreign equity with unrestricted exit policy, easy remittance of royalty, and repatriation of profits and incomes.

- Export Processing Zones: Bangladesh offers exportoriented industrial enclaves with infrastructural facilities and logistical support for foreign investors. The country is also developing its core infrastructures, including roads, highways, surface transport and port facilities for a better business environment.

In Global Ranking Competition of Economics Zones out of 700 Economic Zones globally 200 participated in the competition. All the zones were evaluated on a 10 point scale on the basis of some set criteria. Among the top 10 of the two categories Chittagong Export Processing Zone, Bang- 
ladesh scored 3rd position in the "Best Cost Effectiveness" and also 4th position in the "Best Economic Potential" for 2010-2011.

* Source: Board of Investment Bangladesh, retrived on $05^{\text {th }}$ January 2013, http://boi.gov.bd/about-bangladesh/why-bangladesh

\subsection{Policies to Attract FDI in Bangladesh}

As the FDI showed a great impact on GDP consquently economic so the government should focus on increasing GDP growth. The following are some of the major factors that influence firms to choose to locate their investment in any particular developing country.

- Macroeconomic Factors: Investment is driven by profit, and foreign investors will always prefer a country with a buoyant business sector (measured in terms of GDP growth rate, rate of inflation, level of industrialization, etc.). So Bangladesh should try to increase the GDP growth rate, lowering the inflation rate can attract the foreign investors; the country should improve the level of industrialization or making improving some industry.

- Governance: A country's general structure of governance and the institutions that govern interactions between business and government determine the burden that firms face in complying with government regulations, the quality of government services, and the extent to which corruption is associated with the procurement of these services. Regulations in developing countries may tend to be more complex and bureaucratic than necessary, associated with corruption, and often are not intended to correct market failures or protect consumers. The government of Bangladesh should make fair regulations for FDI and provide the security of investment.

- Infrastructure: The better the infrastructure of the host economy, the more attractive it is to foreign investors. The following infrastructure factors as important in attracting FDI, these include:

- Good base of related and supporting industries (suppliers, sub-contractors, university research centre, business services and raw materials)

- Comfortable nad secured transport facilities (road, rail and air) as well as port system

- Low cost and availability of utilities (telecommunications, energy and water)

- Environmental regulations and procedures

- Availability of sites and premises.

- Bangladesh should ensure these infrastructural facilities to attract the foreign investors to invest in Bangladesh. The communication system, roads, availability of raw materials and energy are more important factors to the foreign investors, so the government should provide all of the facilities.

- Access to Finance and International Integration: Access to finance significantly influences a firm's propensity to invest by foreign investors. Businesses invest in projects where the expected benefits exceed the cost of Copyright $(9$ 2013, Asian Business Consortium | ABR investment. However, this can only be achieved where businesses do not face credit constraints unrelated to their own performance. Credit constraints are less likely in countries with well-developed and well-functioning financial systems. So Bangladesh should ensure the financial facilities and international integration like giving credit, regional co-operation, and well financial system to attract the FDI in Bangladesh. Providing the financial needs is the key factors of doing business in a country the government should ensure the free flow of fund and regulation of collecting the funds of the foreign investors.

- Political Stability: Political certainty and transparency is a very influential determinant for developing countries to attract FDI. Political uncertainty in a potential host country may unexpectedly change the 'rules of the game' under which businesses operate [2]. Political factors like frequent changes of government, critical attitudes of opposition political parties towards FDI lack of transparency in the public service, degree of nationalism, incidence of corruption, and possibilities of terrorism are seriously considered by investors in preinvestment decision making [16]. Instability in a host country's government or monetary and fiscal policies results in more uncertain investment outcomes and detracts from firm value that depress the foreign investors so the government should make the stable political system in the country and the system should be fair for every foreign country.

- Knowledge Infrastructure and Skilled Labor Force: One of the fundamental requirements of economic growth of a country is its knowledge infrastructure and the level of human development. Education, training, health and social services are tools for human resources development. A systematic assessment of availability of human resources is necessary before formulating any policy for attracting FDI [8]. Such policies should be designed to:

- Identify critical shortages of skilled manpower in the various sectors of the economy and take measures to address the reasons for the shortage,

- Develop knowledge development strategies for creating a skilled labor force that foreign investors find advantageous for future growth

- Set targets for human resource development based on reasonable expectations of growth.

So the government should build up facilities to create the educated and skilled labor force so the foreign firm can hire the labor and reduce the unemployment rate of the country. Bangladesh has a very good labor force but there is lack of educated and skilled labor force to attract the foreign countries for FDI. Bangladesh enjoying the lower cost of producing the RMG product because of huge number of labor force in the country but to attract the FDI the country should create skilled labor force. 
- Technology: Technological progress plays an important role in economic growth, which encourages innovation and attracts FDI. A well developed technology infrastructure assists the implementation of better business processes [6]. To support innovation, the public sector can undertake R \& D activities directly - on its own or with private partners to provide complementary services. Whether singly or in combination the factors canvassed above set a substantial policy agenda those developing countries wishing to attract FDI need to address. As some countries are succeeded to attract the foreign investors by availability of technology. Without the technology the productivity can not be increased easily so Bangladesh should improve the technological sector to boost the production and attract the foreign investors.

\subsection{FDI Policymakers Must Consider the Following Issues}

The policy maker of FDI must consider the following issue to promote the more FDI in Bangladesh. The issues are hypothetical and given based on the knowledge gathered from different books, journals, articles and publication so there is prove of the issue.

$\checkmark$ Market liberalization is key ingredients to attract FDI in developing countries.

$\checkmark$ Lack of clear rules, combined with discretionary power wielded by bureaucrats makes it difficult for entrepreneurs to operate efficiently. So the policy maker should make easy, flexible and efficient policies to attract the FDI in Bangladesh.

$\checkmark$ Transnational corporations will locate foreign affiliates in countries where trade rules and regulations are open and forthright to do the business.

$\checkmark$ Countries interested in increasing inward investment must pay attention to other factors that influence investors' location decisions. Among these factors are business facilitation measures which include: investment promotion policies, incentives, after-investment services, improvements in amenities, and measures that reduce the "hassle costs" of doing business in a foreign country.

$\checkmark$ Even though FDI promotion programs involve high human and capital costs, developing nations are spending more money on business facilitation measures so that they can compete with more developed countries for FDI inflows.

$\checkmark$ When it comes to the economic factors, firms that undertake competitiveness-enhancing FDI seek not only cost reduction and bigger market shares, but also access to technology and innovative capacity. These resources, as distinct from natural resources, are manmade created-assets. Created-assets include communications infrastructure, marketing networks, technology and an educated workforce.

$\checkmark$ Transnational corporations are changing the relative importance of different economic determinants of FDI location. Production costs are keys but the host mar- ket is not - access to international markets matter more. Open trade, deregulation and privatization improve access to markets for goods and services.

$\checkmark$ Countries that liberalize their internal regulatory frameworks, sign multilateral trade agreements and join the WTO will be more competitive in attracting FDI.

So the policy makers should consider the above factors and they should ensure the stable economic growth of the country. The regulations should be free and fair for all of the country and the policy makers should make the policy according to the development of the country.

\subsection{Suggestion to Attract FDI in Bangladesh}

After the above study and practical knowledge on the impact of FDI on GDP and the FDI opportunities in Bangladesh, some focal points are discussed below to improve the FDI opportunities in Bangladesh. The following suggestion is based on the assumption, idea and knowledge about the FDI in Bangladesh but there is no empirical proof.

> Sustainable Economic Development: Sustaining macroeconomic stability through maintenance of appropriate monetary and fiscal policy, increasing the Investment/GDP ratio, increasing revenue, improving export performance, sustaining remittance growth, providing productive employment to the labor force and improving business and investment climate. The Central Bank should pursue such monetary policy as would reduce inflation and promote higher growth through maintaining an adequate flow of credit to productive activities.

$>$ Image Building: Improving the currently bad image of doing business in Bangladesh and improving the ranking Bangladesh can attract the foreign investors for FDI. Only branding the country can attract for FDI because at first the foreign investors think about the name and fame of the country to where they want to invest. This requires an increase in political stability; macroeconomic stability; and the protection of property rights as well as the rule of law, easing the getting credit, paying tax and trading across border policy should be easy.

$>$ Marketing Investment Opportunities: Creating awareness of investment opportunities through the use of existing investors and information communication technologies such as the internet. Existing investors play an important role in attracting new investors to new investment locations so the policy makers should provide the investment opportunities to both existing and potential investors.

> Trade Liberalization: Openness to trade will signal commitment to outward-looking, market-oriented policies and enhance trading opportunities thereby attracting foreign investor's intent on taking advantage of the new trading opportunities. The government should liberalize the FDI policies and try to give some tax reduction and incentives. 
> Privatization: The privatization of inefficient stateowned enterprises will boost foreign investment. The privatization of public corporations is necessary to reduce government fiscal deficits.

$>$ Infrastructure and Communication Development: Initiating and encouraging more cooperation in infrastructure and communication development projects for example, in telecommunication, transportation, power generation, and the provision of water ca attract the foreign investors to invest in Bangladesh. This will increase access to and reduce the cost of provision of these facilities, thereby lowering transactions costs, boosting trade, and increasing the attraction of the region to foreign investors.

$>$ Human Resource Development: For human resource development through knowledge base education, training and research, attention had to be given to increase people's access to information, research and capacity development.

\section{CONCLUSION}

Bangladesh has a number of positive attributes that can successfully attract the attention of foreign investors from both developed and developing countries. The increasing availability of skilled and unskilled labor at relatively low wages and the success in maintaining reasonably stable macroeconomic environment are a few factors behind making the country an attractive destination for foreign investors. They are generally aware that the wage rates in Bangladesh are among the lowest in Asian countries, the rate of inflation is usually contained within tolerable limits, the exchange rate is reasonably stable, custom regulations are investment friendly without discrimination between foreign and domestic investors, and attractive incentive packages are available for the foreign investors.

Bangladesh needs to undertake effective promotion measures to convince the potential foreign investors that their involvement in business activities in the country is valued, they would be facing friendly regulations, and they can enjoy investment incentives that are competitive with those offered by other countries in the region and the developing world. The country also needs to move forward through implementing investment friendly policies, simplifying regulatory practices, and removing inefficient bureaucratic procedures.

Based on the foregoing discussion and analysis, it may be stated that as Bangladesh has not yet been successful in creating a favorable environment for attracting sufficient amount of FDI, it is likely that dialing the flows of FDI will remain at the bottom level. The country is lagging behind most of the other regional developing nations in attracting FDI. Therefore, all barriers that stand in the way of industrialization and attracting FDI are required to be overcome.

The infrastructure is number one determining factor in attracting FDI. Poor infrastructure and highly priced utilities in Bangladesh shy away foreign investors from their investCopyright (C) 2013, Asian Business Consortium | ABR ment. In every sector of infrastructure, the availability of quality and reliable services are vital factors in attracting FDI. The corruption of Bangladesh, the most corrupt country in the world, has worsened the investment situation in Bangladesh; therefore, foreign investors have every reason to shy away from investment activities because of political instability and unsatisfactory law and order, which offer them hardly good returns. Even the presence of all positive macro economic indicators like favorable fiscal and monetary policies, abundant supply of labor, good infrastructure support, etc. may not contribute to attract foreign investment due to the singular problem posed by deteriorating law and order situation. Proper steps like the legislation of time-suiting laws and their proper enactment with sincerity can improve the present situation that will help in creating favorable investment climate. FDI inflow more depends on the interest of the foreign investors so the host country should ensure the above policies to ensure the best growth of FDI inflow in Bangladesh to ensure the proper and better economic growth.

\section{REFERENCES}

[1] Chow, P. 1987. Causality between Export and Industrial Development. Journal of development Economics 26: 55-63.

[2] Oman, C. (2000), Policy Competition for Foreign Direct Investment: A Study of Competition among Governments to Attract FDI, OECD Development Centre, Paris.

[3] De Mello, L. (1997), "Foreign Direct Investment in Developing Countries and Growth: A Selective Survey," Journal of Development Studies, 34 (1): 1-34.

[4] Athukorala P. A W., 2003, 'The Impact of Foreign Direct Investment for Economic Growth: A Case Study in Sri Lanka', 9th International Conference on Sri Lanka Studies, 28th- 30th November 2003, Matara, Sri Lanka, Full Paper Number 092.

[5] Markusen. J. and A.J. Venables. 1999. "Foreign Direct Investment as a Catalyst for Industrial Development", European Economic Review, 43: 335-338.

[6] Barrell, R., and N. Pain (1997). 'Foreign Direct Investment, Technological Change, and Economic Growth within Europe', Economic Journal, 107, pp. 1770-1776.

[7] Johnson, A., 2006, 'The Effects of FDI Inflows on Host Country Economic Growth, CESIS Working Paper Series in Economics and Institutions of Innovation, Vol 58, pp. 1-57.

[8] Blomström, M. and F. Sjöholm, (1999), 'Technology Transfer and Spillovers: Does Local Participation with Multinationals Matter?', European Economic Review, vol. 43, pp. 915-923.

[9] Aitken, B.J. and Harrison, A.E, (1999). "Do Domestic Firms Benefit from Direct Foreign Investment? Evidence from Venezuela", American Economic Review, 89, pp. 605-618.

[10] Rodrik, D. (2000), "Can Integration into the World Economy Substitute for a Development Strategy?" World Bank's ABCDEEurope Conference in Paris, June 26-28, 2000.

[11] Hsiao, C., \& Shen, Y. (2003), "Foreign Direct Investment and Economic Growth: The Importance of Institutions and Urbanization," Economic Development \& Cultural Change, 51(4), 883-896.

[12] Choe, J. I. (2003), "Do Foreign Direct Investment and Gross Domestic Investment Promote Economic Growth?," Review of Development Economics, 7(1), 44-57.

$100 \mid \mathrm{P}$ a g e 
[13] Kafi, M.A., Uddin, M.M. \& Islam, M.M, 2007, Foreign Direct Investment in Bangladesh: Problems and Prospects, The Journal of Nepalese Business Studies.

[14] Shimul, S.N., S. M. Abdullah, and S. Siddiqua. 2009. An examination of FDI and growth nexus in Bangladesh: Engle Granger and bound testing cointegration approach. BRAC University Journal, 1: 69-76.

[15] Duasa,J.(2007), "Malaysian Foreign Direct Investment and Growth: Does Stability Matter?," The Journal of Economic Cooperation, 28,2(2007):83-98.

[16] Borensztein, E., J. de Gregorio, and J.-W. Lee (1998), “How Does Foreign Investment Affect Economic Growth?," Journal of International Economics, 45: 115-35.

[17] Barry, F., and J. Bradley (1997), "FDI and Trade: the Irish HostCountry Experience", Economic Journal, 107, pp. 1798-1810.

[18] Policies Towards Foreign Direct Investment in Developing Countries: Emerging Best-Practices and Outstanding Issues by Dirk Willem te Velde, Overseas Development Institute, London, March 2001

[19] Caves, R.E. (1974), "Multinational Firms, Competition and Productivity in Host-Country Markets", Economica, May 1974, 41(162), pp. 176-193.

[20] Balasubramanyam, V.N., M. Salisu, and D. Sapsford (1996), "Foreign Direct Investment and Growth in EP and IS countries", Economic Journal, 106, pp. 92-105.

[21] Blomstrom, M., A. Kokko and M. Zejan (2000a), Foreign Direct Investment. Firm and Host Country Characteristics, MacMillan Press, London.

[22] Anower, H., \& M. K. Hossain, (2012), Empirical Relationship between Foreign Direct Investment and Economic Output in South Asian Countries: A Study on Bangladesh, Pakistan and India, International Business Research, Vol. 5, No. 1; January 2012, www.ccsenet.org/ibr.

[23] Ray, S. (2012), Impact of Foreign Direct Investment on Economic Growth in India: A Co integration Analysis, World Science Publisher, United States, Vol. 2, No. 1, 2012.

\section{APPENDIXES}

Appendix A: GDP (at Current Prices) and FDI Inflow of Bangladesh (In million USD)

\begin{tabular}{|c|c|c|c|c|c|}
\hline Year & GDP & FDI & Year & GDP & FDI \\
\hline $\mathbf{1 9 8 0}$ & 19507 & 8.51 & $\mathbf{1 9 9 6}$ & 41516 & 231.61 \\
\hline $\mathbf{1 9 8 1}$ & 19011 & 5.36 & $\mathbf{1 9 9 7}$ & 43388 & 575.29 \\
\hline $\mathbf{1 9 8 2}$ & 17408 & 6.96 & $\mathbf{1 9 9 8}$ & 44757 & 575.46 \\
\hline $\mathbf{1 9 8 3}$ & 18243 & 0.40 & $\mathbf{1 9 9 9}$ & 46529 & 309.12 \\
\hline $\mathbf{1 9 8 4}$ & 20741 & -0.55 & $\mathbf{2 0 0 0}$ & 47048 & 578.64 \\
\hline $\mathbf{1 9 8 5}$ & 21337 & -6.66 & $\mathbf{2 0 0 1}$ & 47194 & 354.47 \\
\hline $\mathbf{1 9 8 6}$ & 22370 & 2.44 & $\mathbf{2 0 0 2}$ & 49560 & 335.50 \\
\hline $\mathbf{1 9 8 7}$ & 24679 & 3.21 & $\mathbf{2 0 0 3}$ & 54476 & 350.25 \\
\hline $\mathbf{1 9 8 8}$ & 26637 & 1.84 & $\mathbf{2 0 0 4}$ & 59120 & 460.40 \\
\hline $\mathbf{1 9 8 9}$ & 29344 & 0.25 & $\mathbf{2 0 0 5}$ & 61127 & 845.26 \\
\hline $\mathbf{1 9 9 0}$ & 30497 & 3.24 & $\mathbf{2 0 0 6}$ & 65204 & 792.48 \\
\hline $\mathbf{1 9 9 1}$ & 31432 & 1.39 & $\mathbf{2 0 0 7}$ & 73969 & 666.36 \\
\hline $\mathbf{1 9 9 2}$ & 31439 & 3.72 & $\mathbf{2 0 0 8}$ & 84462 & 1086.31 \\
\hline $\mathbf{1 9 9 3}$ & 32954 & 14.05 & $\mathbf{2 0 0 9}$ & 94874 & 700.16 \\
\hline $\mathbf{1 9 9 4}$ & 35802 & 11.15 & $\mathbf{2 0 1 0}$ & 105560 & 913.32 \\
\hline $\mathbf{1 9 9 5}$ & 39580 & 92.30 & $\mathbf{2 0 1 1}$ & 113032 & 1136.40 \\
\hline
\end{tabular}

